\title{
MANAGEMENT OF TOMATO EARLY BLIGHT, CAUSED BY Alternaria solani WITH RESISTANCE INDUCER CHEMICALS (RIC) AND FUNGICIDES
}

\author{
Osama Yosof Mohamed Shalaby \\ Agric. Botany Dept., Fac. Agric., Fayoum University
}

ABSTRACT:

The resistance inducer chemicals (RIC), i.e. Bion, Cobalt chloride, Ecophote, Photophor and Salicylic acid and the two fungicides; i.e. Concento and Score used in this investigation caused different degrees of inhibition to the radial growth of Alternaria solani, the causal fungus of tomato early blight. In general, both of the two aforementioned fungicides were more effective than RIC in reducing the radial growth of $A$. cucumerinum. Also, the reduction in the radial growth increased by increasing the concentration of both the tested RIC and fungicides. Field experiments curried out during 2011 and 2012 growing seasons revealed that both of the tested RIC and fungicides resulted in significant reduction in the natural infection of tomato early blight consequently fruit yield was increased compared with control treatment. On the otherhand, spraying RIC after application of the aforementioned two fungicides was more effective in reducing the disease severity compared with spraying the fungicides or RIC each alone. All applications of RIC and fungicides, each alone resulted in considerable increase to oxidative-reductive enzymes; i.e. polyphenol oxidase, peroxidase and ascorbic acid oxidase compared with control treatment. However, RIC increased enzymatic activity compared with the two tested fungicides.

Key Words: Resistance Inducer Chemicals, Alternaria solani, Tomato early blight, Diseases severity, Enzymatic activity.

\section{INTRODUCTION:}

Tomato (Lycopersiconesculentum L.) is one of the most important solanacious crop in the world as well as in Egypt either for local consumption or exportation. It contains high amount of many nutrient elements and vitamin C. According to the Statistical Dept., Egyptian Ministry of Agriculture and Land Reclamation, the area cultivated with tomato reached more than 450000 feddan, produced about 7150000 ton of fruits with an average of 1.67 ton/feddan during 2010 growing season.

Tomato plants are infected with several fungal diseases. However, early blight disease, caused by Alternaria solani (Ellis and Martin) Jones and Grout is one of the most destructive one, which causes great harmful to the plant growth with considerable reduction to both quantity and quality of the produced fruit yield (Ghoma,2001; Yang-Hua et al, 2004 and Abada et al, 2008).

For a long period, fungicides are known to be the efficient method for reducing the drastically effect of tomato pests including early blight. However, due to consuming huge amounts of tomato fruits freshly, there is an expected dangerous to the human health from the residues of the fungicides used in controlling the disease.

Fayoum J. Agric. Res. \& Dev., Vol. 26, No.2, July, 2012 
Therefore, this work aimed to minimize the residues of the used fungicides in the harvested tomato fruits by making an alternation between spraying fungicides and resistance inducer chemicals. Ashour (2009) found that the applicationof five fungicides, i.e. Consento, Flent, Score, Sereno and Tridex $8 \%$ as well as five antioxidants, i.e. Bion, calcium chloride, lithium sulphate, potassium mono-hydrogen-phosphate and salicylic acid, caused significant reduction in the radial growth of Alternariasolani, the causal of tomato early blight, compared with check treatment. Also, these compounds resulted in significant reduction in the artificial infection as concequently increased the foliage fresh weight of tomato plants compared with check treatment.

Sallam et al, (2012) found that the leaf extracts of Daturastramonium, Allium indica, and $A$. sativumat $5 \%$ concentration caused the highest reduction of mycelial growth of $A$. solani. They also found that greatest reduction of disease severity achieved by $A$. sativumat $5 \%$ concentration, while the smallest reduction was obtained when tomato plants were treated with Ocimum. basilicumat $1 \%$ and 5\% concentration (46.1 and $45.2 \%$, respectively).

\section{MATERIALS AND METHODS:}

\section{1- Effect of RIC and fungicides on the radial growth of Alternaria solani:}

Seven concentrations; i.e. 0, 50,100,250,500.750 and $1000 \mathrm{ppm}$ of five resistance inducer chemicals (RIC), i.e. Bion, Cobalt chloride, Ecophote, Photophor and Salicylic acid were prepared from the crude active materials. The same concentrations were prepared from two fungicides; i.e. Concento (Fenomen 7.5\% + Prompamocarp 37.5) and Score (Difenoconazale $25 \%$ ) depending on their active ingredient. The prepared concentrations of RIC were added to the equivalent amounts of V8 medium (500 ml V8 juice, 3 $\mathrm{g} \mathrm{Ca} \mathrm{Ca} 3$ and $20 \mathrm{~g}$ agar per one liter water) and were evacuated in $250 \mathrm{ml}$ flasks and autoclaved. Meanwhile, fungicides were added after autoclaving the V8 medium. V8 medium free from RIC or fungicides was used as control treatment. The prepared medium was poured just before solidification in sterilized Petri-dishes $(9 \mathrm{~cm}$ in diam.), then inoculated at the center with 5-mm disks taken from the edge of 7-day-old cultures of Alternaria solani. The isolate of A. solani was kindly provided by Plant Pathol. Dept., Fac. Agric., Cairo Univ. Five Petri-dishes were used for each treatment, then incubated at $25 \pm 1^{0} \mathrm{C}$ for 7 days. Radial growth $(\mathrm{mm})$ of all aforementioned treatments was measured.

\section{2- Field experiments:}

Field experiments were carried out at the Farm of Fac. Agric., Fayoum Univ. during 2011 and 2012 growing seasons. The land was prepared for transplanting tomato plants (GS cv.) and divided into plots of $6 \times 7 \mathrm{~m}$. Apparently healthy tomato transplants (free from any visible diseases) were transplanted at the end of March of each season and left grown under the natural infection with $A$. solani, the causal of tomato early blight.Three weeks after transplanting, the plants were sprayed with each of two fungicides, i.e. Concento and Score at 250 and $50 \mathrm{ml} / 100 \mathrm{~L}$ water, respectively.

Fungicides were sprayed three times at two weeks interval until reaching the first formed fruits full green stage (three weeks before harvesting). Two weeks later, the plants were sprayed with aforementioned five RIC at $250 \mathrm{ppm}$ three times at two weeks interval. Plots sprayed with water only were served as control treatment. Both RIC and fungicides were sprayed on the grown plants 6 times. Four plots were used for each treatment and all of the

Fayoum J. Agric. Res. \& Dev., Vol. 26, No.2, July, 2012 
agricultural practices were carried out as recommended by the Ministry of Agriculture and Land Reclamation. The grown plants were carefully inspected for disease incidence one week after each spray and disease severity was measured using the devised scale (0-11) suggested by Towsend and Heuberger (1943) and the averages were recorded. Disease severity percentage was calculated according to the following formula:

$$
\text { Disease severity } \%=\frac{\sum(\mathbf{n x v})}{11 \mathrm{~N}} \times 100
$$

where: $\mathrm{n}=$ Number of plants in each category.

$\mathrm{v}=$ Numerical values of symptoms of each category.

$\mathrm{N}=$ Total number of the inspected plants.

$11=$ Maximum of numerical values of symptoms category.

Tomato fruits were harvested when it was necessary and weighed and the averages were recorded. At the same time, tomato fruits showed early blight symptoms at each harvesting were counted and the average were recorded.

\section{3- Determination of the oxidative-reductive enzymes:}

The activity of polyphenol oxidase, peroxidase and ascorbic acid oxidase were determined in tomato leaves of the plants sprayed with RIC and fungicides each alone. Leaf samples of the grown plants were collected from field experiment of 2012 growing season one week after the fourth spray and taken in ice-box tank to the laboratory for chemical analysis. Both of polyphenol oxidase, peroxidase were determined according to the method of Fehrmann and Dimond (1967). Meanwhile, determination of ascorbic acid oxidase was carried out using method of Maxwell and Bateman (1967).

Statistical analysis:

The obtained data were statistically analyzed according to the standard procedures for split design (radial growth) or split design (field experiments) mentioned by Snedecor and Cochran (1967). The averages were compared at the 5\% level using least significant differences (L.S.D.) according to Fisher (1948).

\section{RESULTS:}

1- Effect of RIC and fungicides on the radial growth of Alternaria solani:

Data in Table (1) show that all the tested resistance inducer chemicals (RIC) and fungicides caused significant reduction in the radial growth of $\boldsymbol{A}$. solani compared with control treatment. In addition, Cobalt chloride, Photophor and Ecophote caused complete inhibition to the radial growth at $500 \mathrm{ppm}$. Bion caused this inhibition at $1000 \mathrm{ppm}$. Meanwhile, Salicylic acid failed to cause complete inhibition to the radial growth at all concentrations. Both of the two fungicides; i.e. Concento and Score were more efficient in this regard compared with the tested RIC, which caused complete inhibition in the radial growth of the tested fungus at 100 and $250 \mathrm{ppm}$. The reduction in the radial growth was increased by increasing the concentration of the tested RIC and fungicides. 
Table (1): Effect of RIC and fungicides on the radial growth of Alternariasolani, 10 days after incubation at $30 \pm 1^{0} \mathrm{C}$.

\begin{tabular}{|l|l|l|l|l|l|l|l|}
\hline \multirow{2}{*}{ Treatments } & \multicolumn{6}{|c|}{ Average of the radial growth $(\mathrm{mm})$ at concentrations } & \multirow{2}{*}{ Mean } \\
\cline { 2 - 8 } & 50 & 100 & 250 & 500 & 750 & 1000 & \\
\hline RIC: & 70.4 & 53.8 & 41.0 & 27.6 & 14.0 & 0.0 & 34.5 \\
\hline Bion & 55.0 & 37.2 & 22.2 & 10.0 & 0.0 & 0.0 & 19.1 \\
\hline Cobalt chloride & 68.0 & 49.6 & 31.0 & 16.4 & 0.0 & 0.0 & 27.2 \\
\hline Ecophote & 63.6 & 46.0 & 28.8 & 13.0 & 0.0 & 0.0 & 25.2 \\
\hline Photophor & 87.2 & 78.4 & 66.0 & 47.2 & 35.0 & 20.8 & 55.8 \\
\hline Salicylic acid & & & & & & & \\
\hline Fungicides: & 50.2 & 34.0 & 18.0 & 0.0 & 0.0 & 0.0 & 47.2 \\
\hline Concento & 16.8 & 0.0 & 0.0 & 0.0 & 0.0 & 0.0 & 9.5 \\
\hline Score & 90 & 90 & 90 & 90 & 90 & 90 & 90 \\
\hline Control & 69.4 & 56.0 & 42.5 & 31.5 & 19.6 & 13.9 & \\
\hline Mean & & & & & & & \\
\hline
\end{tabular}

L.S.D. at $5 \%$ for: Treatment $(\mathrm{T})=3.4$, Concentrations $(\mathrm{C})=2.7$ and $\mathrm{T} \times \mathrm{C}=4.3$

\section{2- Effect of RIC and fungicides on tomato early blight severity and fruit} yield:

Data in Table (2) reveal that the tested RIC and fungicides either used alone or in combinations, caused significant reduction in the severity of the natural infection with tomato early blight on the foliage growth and number of the infected fruits, concequently the fruit yield was increased compared with control treatment.

In general, both fungicides; i.e. Concento and Score were more effective in reducing disease severity and the infected fruits as well as increasing fruit yield, being 3.4\%, $0.6 \%$ and $98.7 \mathrm{~kg}$ for Concento and $3.0 \%, 0.4 \%$ and 99.8 $\mathrm{kg}$ for Score, respectively compared with RIC, being $19.1 \%, 12.1 \%$ and 64.4 $\mathrm{kg}$ for Bion, $17.2 \%, 11.5 \%$ and $67.5 \mathrm{~kg}$ for Cobalt chloride, $18.6 \%, 12.0 \%$ and $65.6 \mathrm{~kg}$ for Ecophote, $18.0 \%, 11.7 \%$ and $66.3 \mathrm{~kg}$ for Photophor and 14.1\%, $9.0 \%$ and $70.0 \mathrm{~kg}$ for Salicylic acid.

When the two fungicides were sprayed at the first period of the growth, after transplanting until reaching the fruits pre-mature stage (three weeks before harvesting), then RIC sprayed two weeks before harvesting and during harvesting.This combination reduced the disease incidence and increased the fruit yield compared with using RIC alone. Control treatment recorded 52.5\% disease severity, $12.8 \%$ infected fruits and $48.7 \mathrm{~kg}$ fruits $/$ plot $\left(21 \mathrm{~m}^{2}\right)$.

In all cases, no significant differences were detected between the values of diseases severity, number of the infected fruits and fruit yield due to the effect of the growing season. 
Table (2): Effect of spraying tomato plants (GS cv.) with RIC after application of two fungicides on the severity of infection by early blight and fruit yield under field condition during 2011 and 2012 growing seasons.

\begin{tabular}{|c|c|c|c|c|c|c|c|c|c|}
\hline \multirow[t]{2}{*}{ Treatments } & \multicolumn{2}{|c|}{$\begin{array}{c}\text { \% Disease } \\
\text { severity } \\
\text { during }\end{array}$} & \multirow[t]{2}{*}{ Mean } & \multicolumn{2}{|c|}{$\begin{array}{c}\text { No. of the } \\
\text { infected fruits } \\
\text { during }\end{array}$} & \multirow[t]{2}{*}{ Mean } & \multicolumn{2}{|c|}{$\begin{array}{c}\text { Fruit yield } \\
\text { (kg)/plot } \\
\text { during }\end{array}$} & \multirow[t]{2}{*}{ Mean } \\
\hline & \begin{tabular}{|l|}
2011 \\
\end{tabular} & 2012 & & 2011 & 2012 & & 2011 & 2012 & \\
\hline Bion (B) & \begin{tabular}{|l|}
19.2 \\
\end{tabular} & 19.0 & \begin{tabular}{|l|}
19.1 \\
\end{tabular} & 4.2 & 4.0 & 4.1 & 63.8 & 65.0 & 64.4 \\
\hline Cobalt chloride (CC) & 17.3 & 17.1 & 17.2 & 3.6 & 3.4 & 3.5 & 67.0 & 68.0 & 67.5 \\
\hline Ecophote (E) & 18.7 & 18.5 & 18.6 & 4.0 & 4.0 & 4.0 & 65.2 & 66.0 & 65.6 \\
\hline Photophor (P) & 18.0 & 18.0 & 18.0 & 3.8 & 3.6 & 3.7 & 66.0 & 66.5 & 66.3 \\
\hline Salicylic acid (Sa) & 14.6 & 13.5 & 14.1 & 2.6 & 2.4 & 2.5 & 69.6 & 70.4 & 70.0 \\
\hline Concento (Co) & 3.5 & 3.2 & 3.4 & 0.6 & 0.6 & 0.6 & 98.5 & 98.8 & 98.7 \\
\hline Score $(\mathbf{S})$ & 3.0 & 2.9 & 3.0 & 0.4 & 0.4 & 0.4 & 100 & 99.5 & 99.8 \\
\hline Co then B & 7.9 & 7.6 & 7.8 & 2.2 & 2.0 & 2.1 & 93.8 & 93.4 & 92.0 \\
\hline Co then CC & 6.0 & 5.7 & 5.9 & 2.0 & 1.8 & 1.9 & 95.4 & 95.6 & 95.5 \\
\hline Co then $\mathrm{E}$ & 7.2 & 7.0 & 7.1 & 2.2 & 2.2 & 2.2 & 93.2 & 94.0 & 93.6 \\
\hline Co then $P$ & 7.0 & 7.0 & 7.0 & 2.0 & 2.2 & 2.1 & 93.2 & 94.0 & 93.6 \\
\hline Co then Sa & 5.3 & 5.0 & 5.2 & 1.8 & 1.8 & 1.8 & 95.6 & 96.0 & 95.8 \\
\hline$S$ then B & 7.5 & 7.2 & 7.5 & 2.0 & 2.0 & 2.0 & 94.0 & 94.8 & 94.4 \\
\hline$S$ then $\mathrm{CC}$ & 5.7 & 5.5 & 5.6 & 1.4 & 1.6 & 1.5 & 95.0 & 95.0 & 95.5 \\
\hline$S$ then $\mathbf{E}$ & 7.0 & 7.0 & 7.0 & 1.8 & 1.6 & 1.7 & 94.3 & 95.0 & 94.7 \\
\hline$S$ then $P$ & 6.8 & 6.7 & 6.8 & 1.8 & 1.8 & 1.8 & 96.4 & 97.0 & 96.7 \\
\hline$S$ then $\mathrm{Sa}$ & 5.0 & 5.0 & 5.0 & 1.0 & 1.0 & 1.0 & 97.2 & 97.6 & 97.4 \\
\hline Control & 53.1 & 51.8 & 52.5 & 12.6 & 13.0 & 12.8 & 48.6 & 48.8 & 48.7 \\
\hline Mean & 11.8 & 11.5 & & 2.8 & 2.7 & & 80.6 & 81.7 & \\
\hline
\end{tabular}

LSD at $5 \%$ for Treatment $(\mathrm{T})=2.8$

Season $(S)=$ N.s.

$\mathrm{T} \times \mathrm{S}=3.0$

3- Activity of the oxidative-reductive enzymes affected by the tested RIC and fungicides:

Data shown in Table (3) show that both the tested RIC and fungicides caused considerable increasement in the oxidative-reductive enzymes; i.e. polyphenol oxidase, peroxidase and ascorbic acid oxidase compared with control treatment.

In general, the activity of ascorbic acid oxidase was more higher than that of peroxidase and polyphenol oxidase. Furthermore, RIC resulted in higher enzymatic activity than the two tested fungicides. In addition, Salicylic acid resulted in the highest activity $(0.62,0.83$ and 0.93 , for polyphenol oxidase, peroxidase and ascorbic acid oxidase, respectively), followed by Photophor (0.56, 0.71 and 0.86, respectively). Meanwhile, Bion recorded the lowest activity (0.51, 0.68 and 0.80 in the same respect) followed by Ecophote, being $0.55,0.72$ and 0.83 , respectively. Concento recorded $0.41,0.57$ and 0.0 for the activity of the tested enzymes, respectively. While Score recorded $0.42,0.60$ and 0.73 , for the enzymatic activity respectively. Control treatment recorded $0.36,0.49$ and 0.53 , respectively.

Fayoum J. Agric. Res. \& Dev., Vol. 26, No.2, July, 2012 
Table (3): Activity of polyphenol oxidase, peroxidase and ascorbic acid oxidase due to spraying tomato plants (GS cv.) with some RIC and fungicides.

\begin{tabular}{|l|c|c|c|c|}
\hline \multirow{2}{*}{ Treatments } & \multicolumn{3}{|c|}{ Activity of enzymes } & \multirow{2}{*}{ Mean } \\
\cline { 2 - 4 } & $\begin{array}{c}\text { Polyphenol } \\
\text { oxidase }\end{array}$ & Peroxidase & $\begin{array}{c}\text { Ascorbic } \\
\text { acid }\end{array}$ & \\
\hline RIC: & 0.51 & 0.68 & 0.80 & 0.66 \\
\hline Cion & 0.57 & 0.76 & 0.86 & 0.73 \\
\hline Ecobalt chloride & 0.55 & 0.70 & 0.83 & 0.69 \\
\hline Photophote & .56 & 0.71 & 0.86 & 0.72 \\
\hline Salicylic acid & 0.62 & 0.83 & 0.93 & 0.79 \\
\hline Fungicides: & 0.41 & 0.57 & 0.70 & 0.55 \\
\hline Concento & 0.42 & 0.60 & 0.73 & 0.58 \\
\hline Score & 0.36 & 0.49 & 0.53 & 0.46 \\
\hline Control & 0.49 & 0.67 & 0.79 & \\
\hline Mean & & & & \\
\hline
\end{tabular}

** Expressed as absorption after 30 seconds.

\section{DISCUSSION:}

The obtained data show that the tested resistance inducer chemicals (RIC); i.e. Bion, Cobalt chloride, Ecophote ,Photophor and Salicylic acid and two fungicides, i.e. Concento and Score gave different degrees of inhibitory affect on the radial growth of Alternariasolani. In addition, the two fungicides were more effective in this regard compared with RIC.The high inhibitory effect of the two tested fungicides was expected, where they are recommended for controlling tomato early blight disease caused by Alternariasolani (Louws et al, 1996; Yang-Hua et al, 2004; Abada et al, 2008 and Ashour, 2009).

It has been found that both the tested RIC and fungicides either used alone or in combination resulted in significant reduction in the disease severity and the number of the infected fruits, concequently fruit yield was increased compared with control treatment. In addition, the two fungicides were more effective than RIC when used each alone. Meanwhile, when the two fungicides were sprayed three times beginning three weeks after transplanting until forming full green fruits, followed by RIC for three sprays also, before maturity of the fruits and during harvesting resulted in significant reduction of the disease severity and increasement in fruit yield. World is suffering from great pollution from agrochemicals which cause many hazards to the environment and human health, the present work was planned to reduce the residues of the sprayed fungicides in tomato fruits by prolonging the period after their spray and using RIC before and during harvesting the fruits. This maybe due to the plants grow for a long period after transplanting with low disease severity and the plants gave most fruits. Therefore, such produced fruits are preferable where they have low residue from the used fungicides. The use of RIC in minimizing plant diseases was frequently reported by many authers (Mosa, 1997; Ivanovicet al, 2002; Abdel-Kareem et al, 2004; Abada et al, 2008, and Sallam et al, 2012). Lancke (1981) found that unlike elecitors of phytoalexinsaccumulation, which are elicited at the sits of application may be responsible for localized protection and induces systemic acquired resistance that synsitizes the plant responses rapidly after infection.

Fayoum J. Agric. Res. \& Dev., Vol. 26, No.2, July, 2012 
These responses induced phytoalexins accumulation and lignification (Kuc and Ruch, 1985) and induce or enhance activities of chitinaseand glucanase (Metranx and Baller, 1986). Furthermore, Kessman et al, 1994 reported that the mechanism of systemic acquired resistance is apparently multificated likely resulting in stable, broad spectrum disease control and they could be used preventatively to bolster general plant health resulting in long lasting protection. It has been found that the tested RIC and fungicides resulted in considerable increase in the activity of enzymes polyphenol oxidase, peroxidase and ascorbic acid oxidase compared with control treatment.In addition, RIC were of higher activity than fungicides, especially Salicylic acid. The activation of the estimated enzymes could be occurred using many chemicals as spray on the tomato plants (Thiribhuvanamala et al, 2001; Ivanvic et al, 2002; Wickramaarachi et al, 2003, Abada et al, 2008, and Ashour, 2009). For a long period an attention was given to the role of oxidative-reductive enzymes in the defense mechanism of the infected plants by plant pathogens. The increase in enzymatic activity may be lead to increasing the level of oxidized phenol, which have two effects (1) production of phenols highly toxic to the pathogen and (2) reduction in the total phenols content due to enhancement of phenol polymerization process, which decreases the amount of extractable phenols (Farkas and Kiraly, 1962). They added that the participation of an endogenous supply of phenolic compounds in plant disease resistance is depended upon active of polyphenol oxidase system. Also, phenols were oxidized to quinines and semiquinones, having antimicrobials role.

REFERENCES:

Abada, K.A.; S.H. Mostafa and Mervat, R. Hilall (2008). Effect of some chemical salts on suppressing the infection of early blight disease of tomato.Egypt. J. of Appl. Sci., 23 (2 A), 47-58.

Abdel-Kareem, F.; Nehal S. El-Mougy; Nadia El-Gamal and Y.O. Fotouh (2004). Induction of resistance in squash plant against powdery mildew and Alternaria leaf spot disease using chemical inducers as protective or therapeutic treatments. Egypt. J. Phytopathol., 32:65-76.

Ashour, A.A. (2009). A Protocol Suggested for Managing Tomato Early Blight. Egypt. J. Phytopathol., Vol. 37, No. 1, pp. 9-20 (2009).

Farkas, C. and L. Kiraly (1962). Role of phenolic compounds in the physiology of plant disease and disease resistance. Phytopathol. Z., 44:106-150.

Fehrman, H. and A.E. Dimond (1967). Peroxidase activity of Phytophthora resistance in different organs of potato plants. Phytopathology, 57: 69-72.

Fisher, R.A. (1948). Statistical Methods for the research workers. Oliver and Boyd, London, U.K.

Ghoma, A.M. (2001). Pathological studies on early blight tomato. M. Sc. Thesis, Fac. Agric., Cairo Univ.

Ivanovic, M.; M. Mijatovic and D. Antonijevic (2002). Effect of sodium bicarbonate on Alternaria solani on tomato. Acta Hortic., 579:535-539

Kessmann, H.; T. Staub; C. Hofmann;T. Meatzke and J. Herzog (1994). Induction of systemic acquired disease resistance in plants by chemicals. Ann Rev. Phytopthol., 32: 439- 459.

Kuc, J. and J. Rush (1985). Phytoalexin. Arch Biochem.,Biophys., 236: 379 389.

Fayoum J. Agric. Res. \& Dev., Vol. 26, No.2, July, 2012 
Lancake, P. (1981). Alternative chemical agents for controlling plant iseases.Phil.Trans., R. Soc., London, B 295: 83-101.

Locke, S.B. (1949). Resistance to early blight and septoria leaf spot in the genus Lycopersicon. Phytopathology, $39: 829-836$.

Louws, F.; M.K. Hausbeck; J. Kelly and C. Stephens (1996). Impact of reduced fungicides and tillage on foliar blight, fruit rot and yield of processing tomatoes. Plant Dis., 80:1251-1256.

Metranx, J.P. and T. Boller (1986). Local and systemic induction of chitnase in Cucumber plants in response to fungal, bacterial and viral infection. Physiol., Mol. Plant Pathol., 28:161-169.

Mosa, A.A. (1997). Effect of foliar application of phosphates on cucumber Powdery Mildew Ann Agric. Sci., 42:241-255.

Sallam M.A. Nashwa and K. A. Abo-Elyousr (2012). Evaluation of Various Plant Extracts against the Early Blight Disease of Tomato Plants under Greenhouse and Field Conditions. Vol. 48, 2012, No. 2: 74-79 Plant Protect. Sci.

Snedecor, G.W. and C.G. Coshran (1967). Statistical Methods, 6 th ed., Iwa State Univ. Press, Ames, Iwa, USA.

Thiribhuvanamala, G.; G. Ramakrishnan and S. Doraswamy (2001). Effect of plant products against Alternariasolani, the early blight pathogen of tomato. South Indian Hortic., 49:257-260.

Towssend, G.K. and T.W. Heuberger (1943). Methods for estimating losses caused by diseases in fungicide experiments. Plant Dis., 2:340-343.

Wickramaarachi, W.A.; P.N. Reddy; T.V. Reddy and P.V. Rao (2003). Induction of Resistance in tomato against early blight disease with nonConventional chemicals. Annals Sri Lanka Dept., Agric, 5:271-279.

Yang-Hua; Cui-Yuanyu;Gan-Zhongxiang; Sum-Xiaojum (2004). The efficacy of Novel fungicides to control early blight of processing tomato. Xinjiang Agric. Sci., 41(5):363-366.

$$
\begin{aligned}
& \text { مكافحة الندوة المبكرة في الطماطم المسبب عن الفطر ألترناريا سولاني }
\end{aligned}
$$

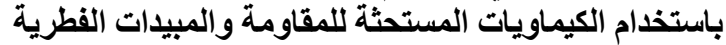

$$
\begin{aligned}
& \text { قسم النبات الزراعى ، كلية الزراعة شبلى جامعة الفيوم }
\end{aligned}
$$

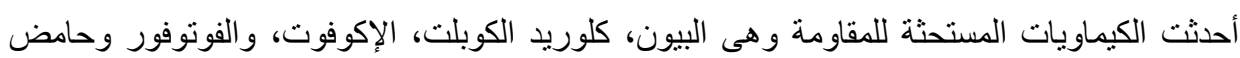

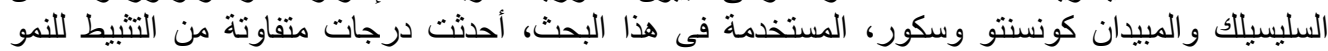

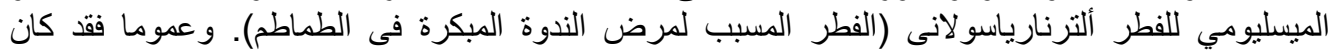

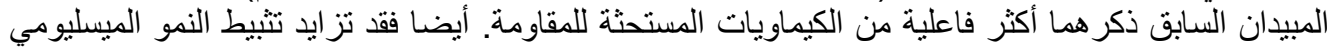

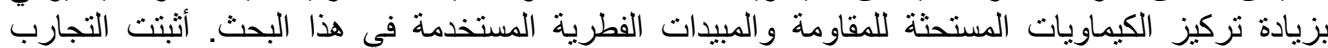

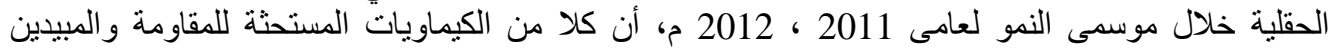

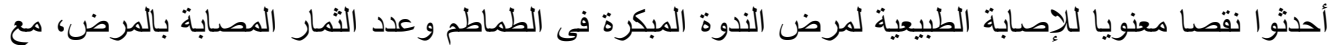

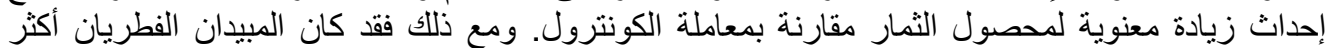

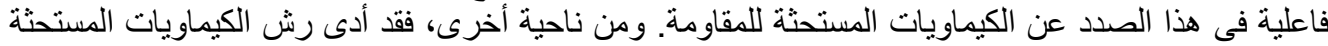

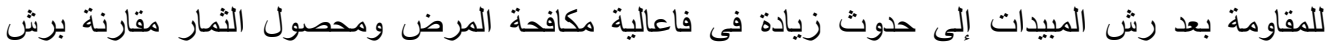

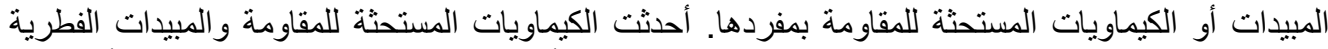

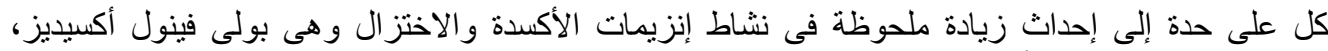

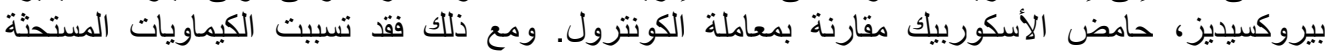
لالمقاومة فى زيادة النشاط الإنزيمي بالمقارنة مع المبيدين المختبرين.

Fayoum J. Agric. Res. \& Dev., Vol. 26, No.2, July, 2012 